\title{
Relationship between the physical size, incompetence, and stenosis of prosthetic mitral valves
}

\author{
J. T. M. WR I GH T and L. J. TEMPLE \\ Bio-Engineering and Medical Physics Unit (Department of Surgery), University of Liverpool, \\ and Cardio-thoracic Surgical Centre, Broadgreen Hospital, Liverpool
}

\begin{abstract}
One each of 17 commercially available prosthetic mitral valves has been subjected to in vitro testing using a pulse duplicator. Measurements of mean diastolic pressure difference, incompetence, dimensions, mechanical movements, and turbulence were made, and the quality of manufacture was examined. Although most valves would be effective in the treatment of incompetence, only those with large orifice diameters produced no significant stenosis. All the valves tested were in clinical use at some time in the period 1966-71. Most of the prostheses were obtained in 1968 or 1969. Many of this group showed a manufacturing standard which was less than impeccable.
\end{abstract}

Replacement of a diseased mitral valve with a prosthesis is usually undertaken because of stenosis and/or incompetence produced by the defective valve. It is, therefore, important that the diastolic pressure difference across the prosthesis should be appreciably lower than the diastolic pressure difference found in a moderate stenosis, and the incompetence produced should be less than a moderate incompetence in the diseased valve. If this were not so there would be little point in replacing any but the most severely damaged valves, and it is patients with this severity of the disease who are the poorest surgical risks.

The correction of gross incompetence often allows the dilated atrium and ventricle to shrink back to their pre-diseased size. Thus a ventricular cavity which is large at the time of surgery could encourage the surgeon to insert too large a valve. When after recovery the ventricular cavity is greatly reduced in size, the cage of the ball valve can impinge on the endocardium, causing laceration and death (Yates, 1969 ; Kalke et al., 1969). Conversely, the use of too small a prosthesis will result in a stenosis. Patients who have both aortic and mitral stenosis display myocardial hypertrophy, which reduces the internal volume of the ventricle. In this group, often requiring double valve replacement, the dimension of the mitral valve will be critical and the use of a low profile mitral valve may be preferred.

In considering the choice of a mitral valve replacement the cardiac surgeon should be aware of the relative diastolic pressure difference, incom- petence, and dimensional characteristics of all available prostheses in order that the optimum type and size can be selected for a given patient.

These characteristics have been measured for a selection of mitral valve prostheses and in this paper the results are presented, together with some observations made on the dynamic movements, flow disturbance, and quality of manufacture and design.

Since this work was begun there have been a number of changes as regards design, finish or availability of particular valves, as noted below. Of those models incorporating such change of design or finish the Starr Edwards $6310^{1}$ is the only one which has been tested.

\section{TESTS CARRIED OUT}

Seventeen mitral valve prostheses representing a range of disc and ball valves and a flap valve were obtained mainly through normal commercial channels. For reasons of economy some of the valves tested had been clinically used for short periods before testing. No significant tissue deposit was evident on these valves unless stated. Three forms of comparison have been made:

1. comparison between a variety of valves with an annulus diameter of $30-31 \mathrm{~mm}$;

2. comparison between a range of StarrEdwards model 6300 sizes $1 \mathrm{M}, 2 \mathrm{M}, 3 \mathrm{M}$, and $4 \mathrm{M}$ valves;

1 The Starr Edwards 6310 is a modified model-See p. 301. 

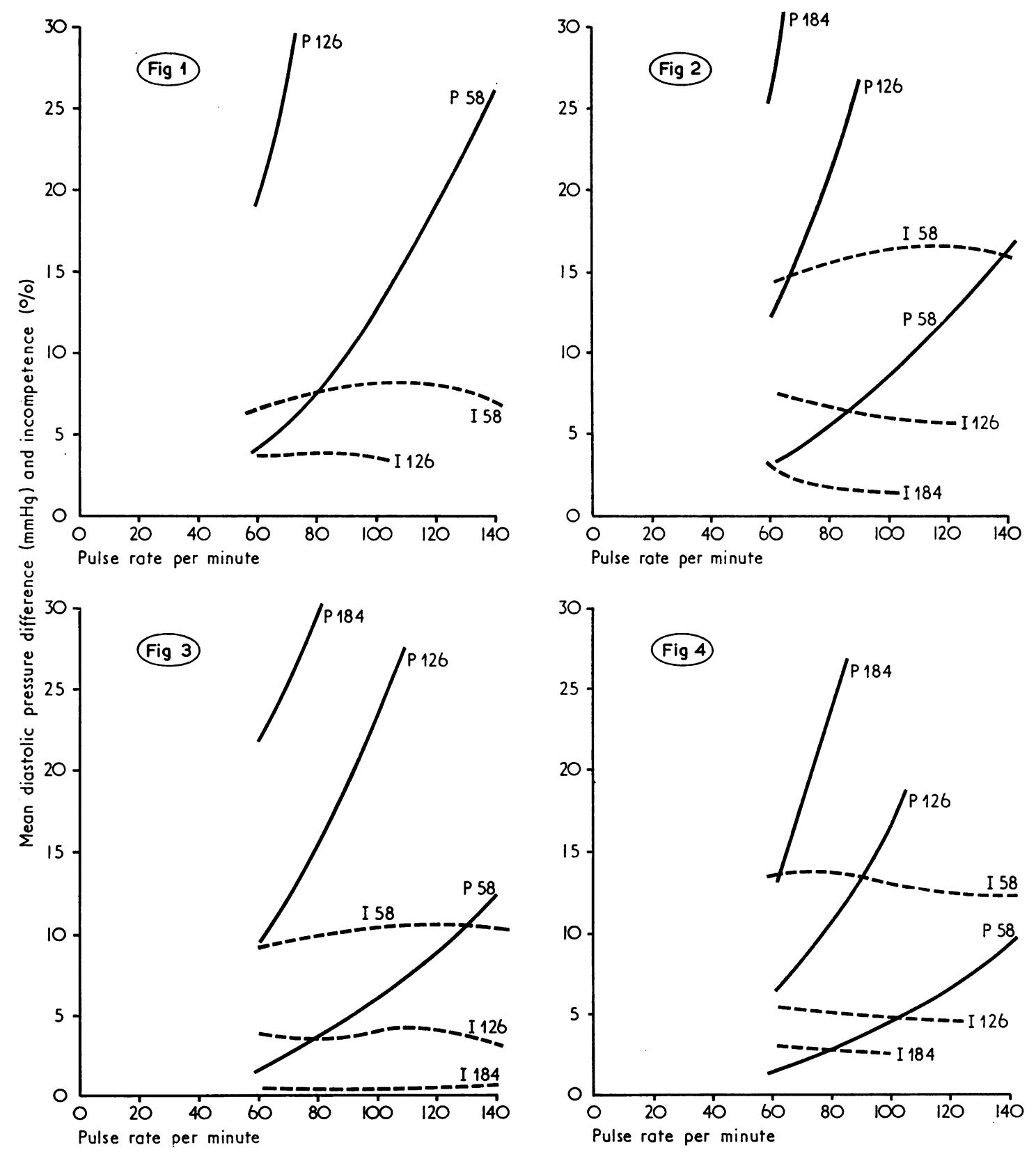

FIG. 1. Starr-Edwards $6300 / 1 M$ prosthetic mitral valve. FIG. 2. Starr-Edwards $6300 / 2 M$ prosthetic mitral valve.

$P=$ mean diastolic pressure difference; $I=$ incompetence; number following $=$ stroke volume $(\mathrm{ml})$.

FIG. 3. Starr-Edwards $6300 / 3 M$ prosthetic mitral valve.

FIG. 4. Starr-Edwards $6300 / 4 M$ prosthetic mitral valve. 

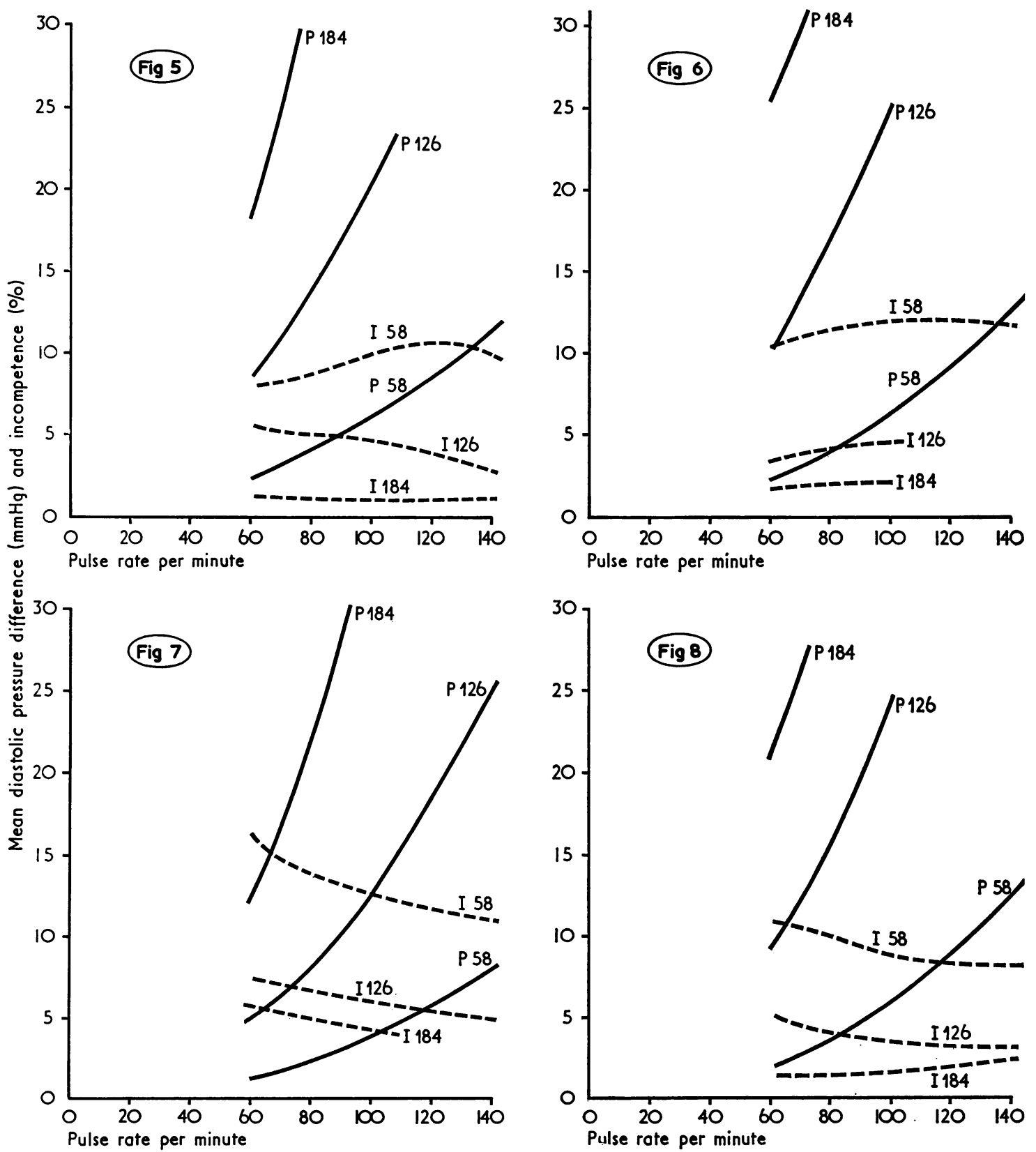

FIG. 5. Starr-Edwards $6120 / 3 M$ prosthetic mitral valve.

FIG. 6. Lusterlite size 3 prosthetic mitral valve.

FIG. 7. Smeloff-Cutter $M 7$ prosthetic mitral valve.

FIG. 8. Starr-Edwards $6500 / 3 M$ prosthetic mitral valve. 

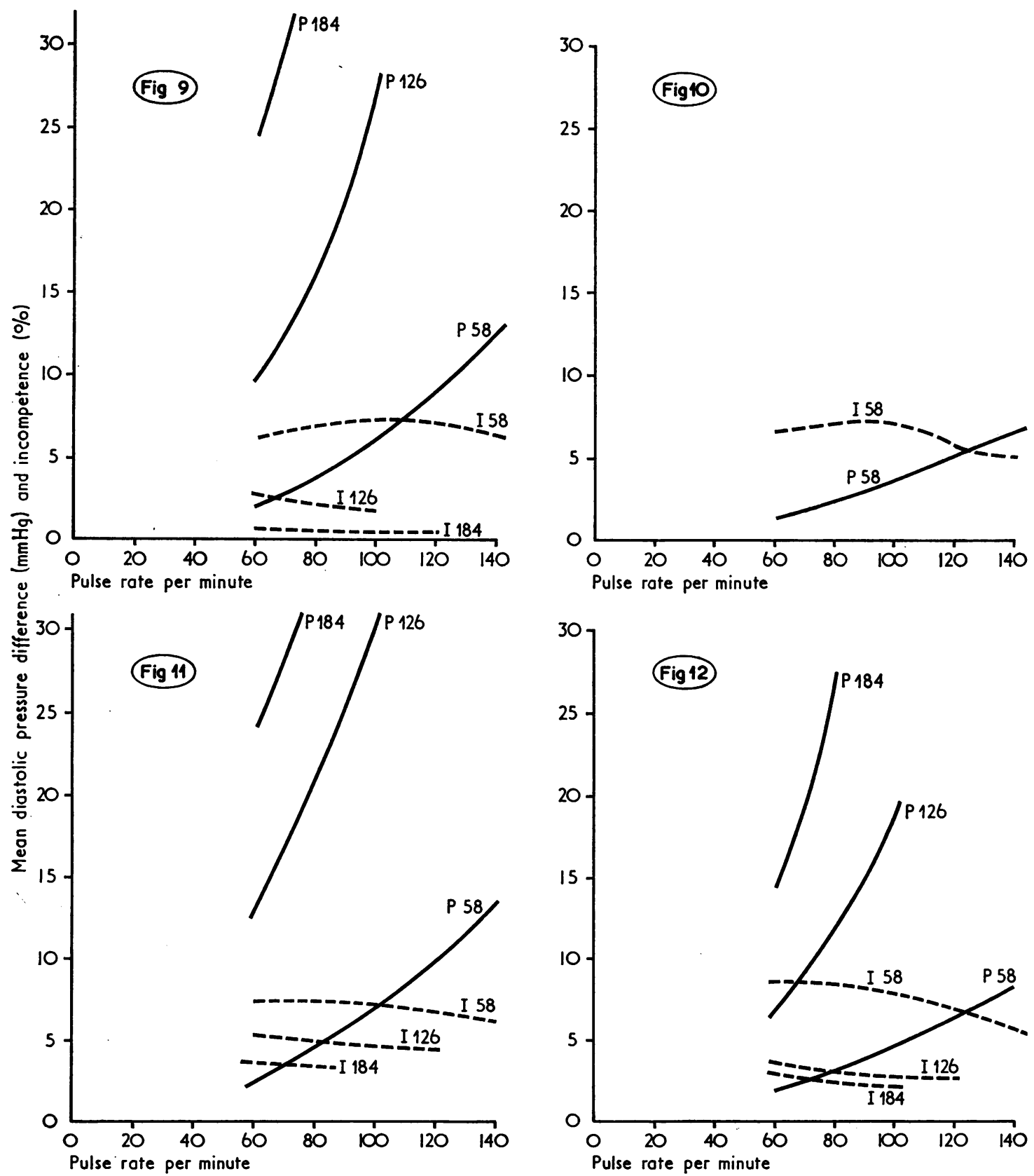

FIG. 9. Cooley-Bloodwell-Cutter 31 prosthetic mitral valve.

FG. 10. Hufnagel discoid size 11 prosthetic mitral valve.

FIG. 11. Portex-Hammersmith P1 prosthetic mitral valve.

FG. 12. Beall Medium prosthetic mitral valve. 

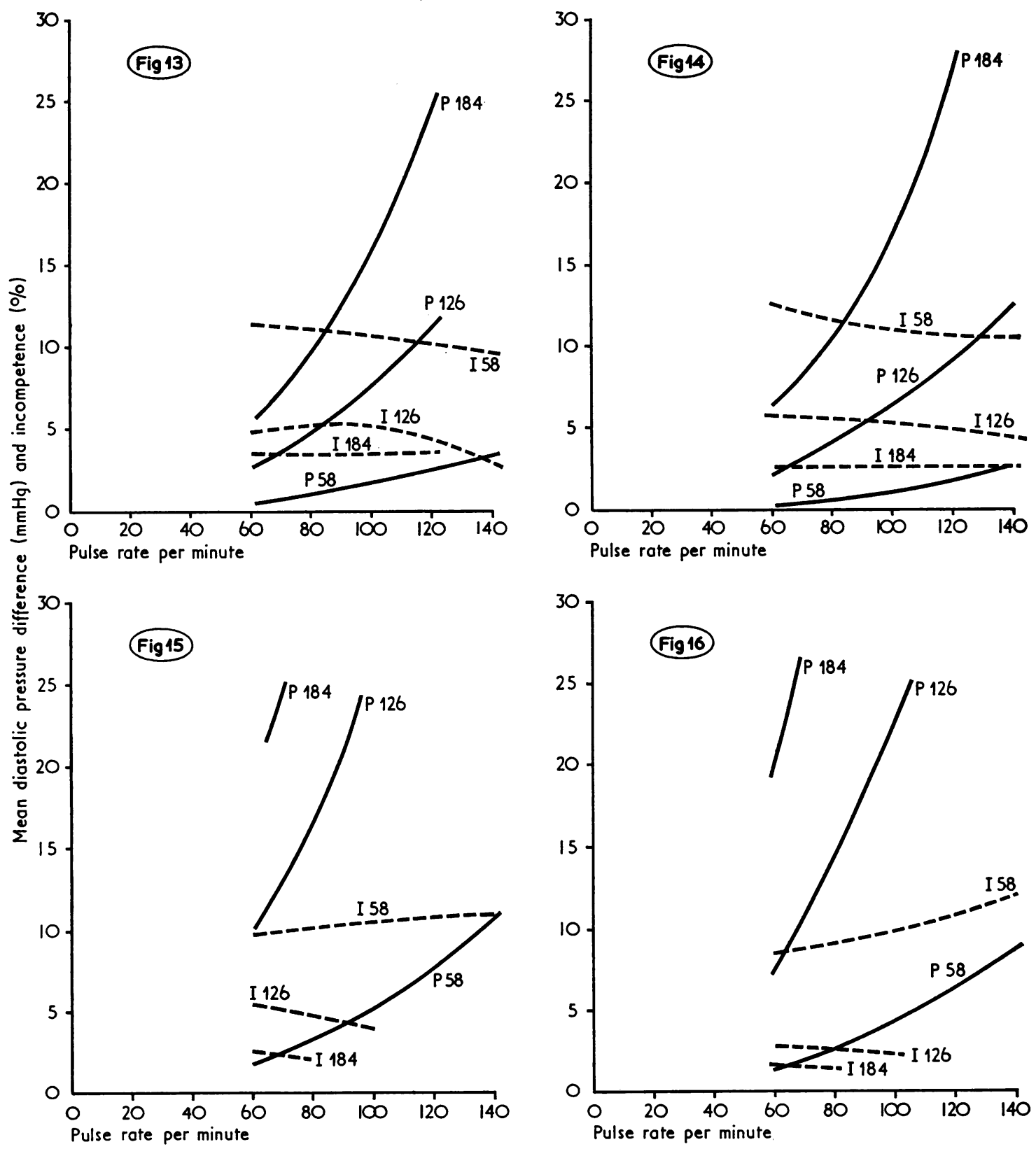

FIG. 13. University of Cape Town M23 prosthetic mitral valve.

FIG. 14. Abrams-Lucas prosthetic mitral valve.

FIG. 15. Starr-Edwards $6310 / 2 M$ prosthetic mitral valve.

FIG. 16. Starr-Edwards $6310 / 3 M$ prosthetic mitral valve. 
3. comparison between a range of StarrEdwards model 6310 sizes $2 M, 3 M$, and $4 M$ valves.

In some cases, e.g., the Abrams-Lucas valve (which has not been released for general use), an alternative annulus size had to be selected as no

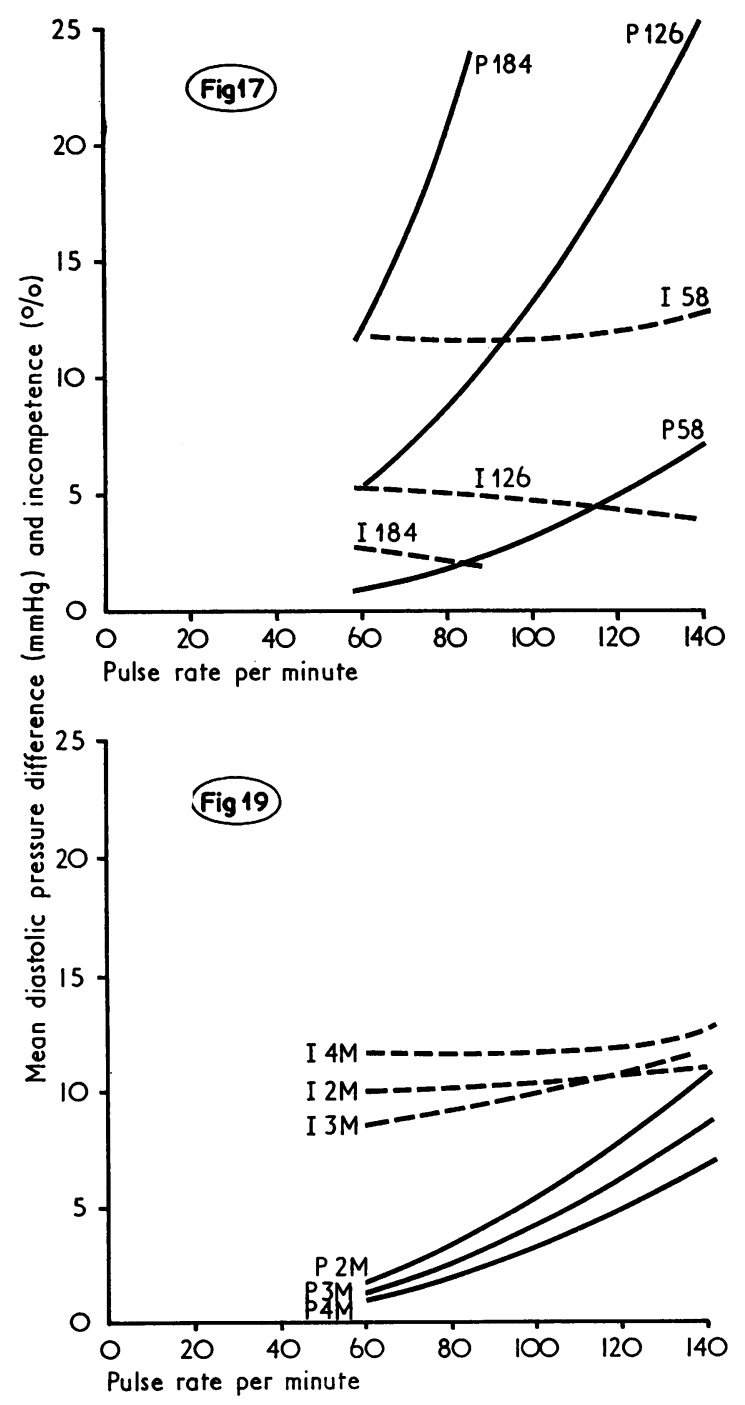

model of 30-31 mm annulus diameter was manufactured.

The tests carried out on the prostheses were to determine:

(a) the mean diastolic pressure difference,

(b) the incompetence,
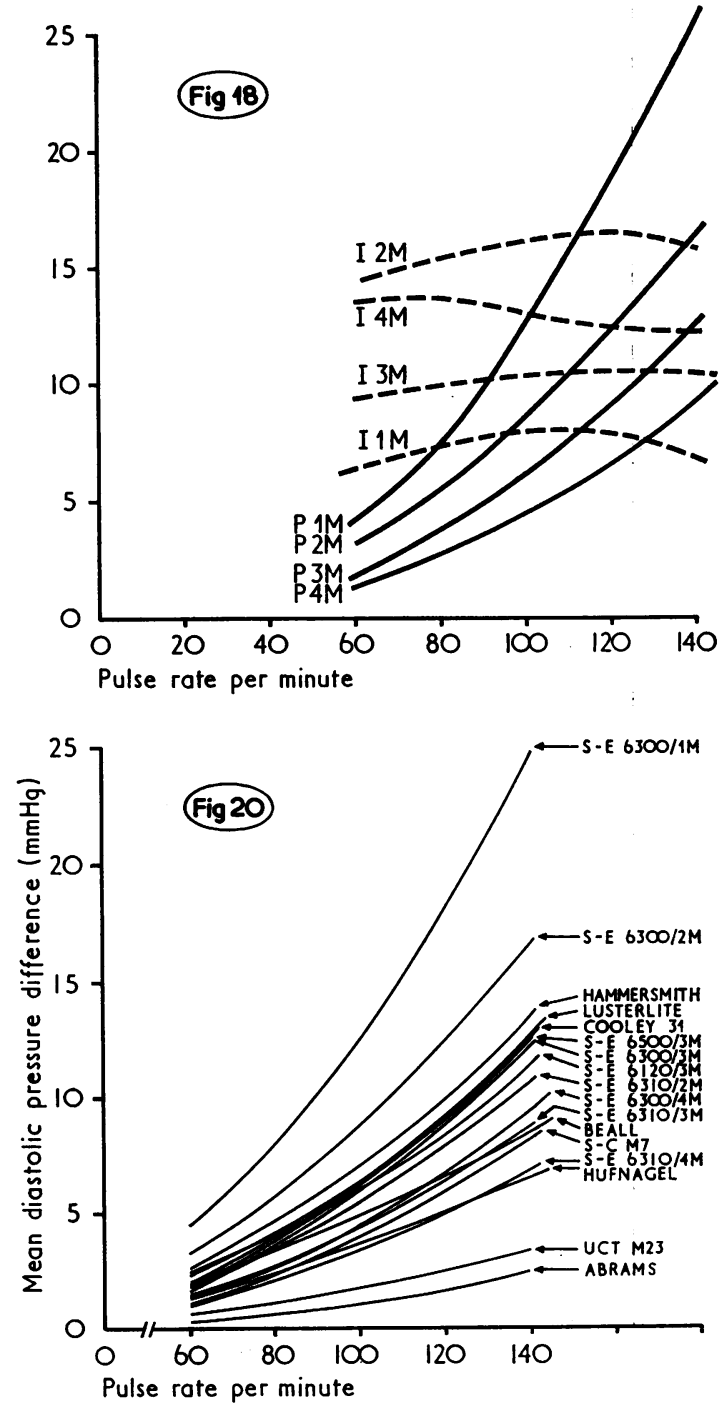

FIG. 17. Starr-Edwards $6310 / 4 M$ prosthetic mitral valve.

FIG. 18. Comparison of mean diastolic pressure differences and percentage incompetences of sizes $1 M$ to $4 M$ of StarrEdwards 6300 mitral valve prosthesis at a stroke volume of $58 \mathrm{ml}$.

FIG. 19. Comparison of mean diastolic pressure differences and percentage incompetences of sizes $2 M$ to $4 M$ of StarrEdwards 6310 mitral valve prosthesis at a stroke volume of $58 \mathrm{ml}$.

FIG. 20. Comparison of mean diastolic pressure differences of all the prosthetic mitral valves at a stroke volume of $58 \mathrm{ml}$. 
(c) valve action by cinephotography,

(d) the flow disturbances caused by the valve,

(e) the principal dimensions, and

$(f)$ the quality of workmanship in its construction and an opinion of design weaknesses.

The pulse duplicator (Wright and Temple, 1971) utilized a rigid testing chamber resembling the left atrium and ventricle in size and shape. The test fluid was water glycerine at $25^{\circ} \mathrm{C}$ with a viscosity of 3.0 centiPoise and a specific gravity of 1.088. The pulse duplicator piston was driven in a sinusoidal manner over a range of $60-140$ pulses per minute at stroke volumes of 58, 126, and $184 \mathrm{ml}$ per stroke. This simulated cardiac outputs in the range 3.5-30 litres/minute.

Previously, we referred to the mean diastolic pressure difference as the mean diastolic gradient (Wright and Temple, 1971). The term 'gradient' is well understood but not strictly accurate and so in this paper and in future we shall use the expression 'mean diastolic pressure difference'.

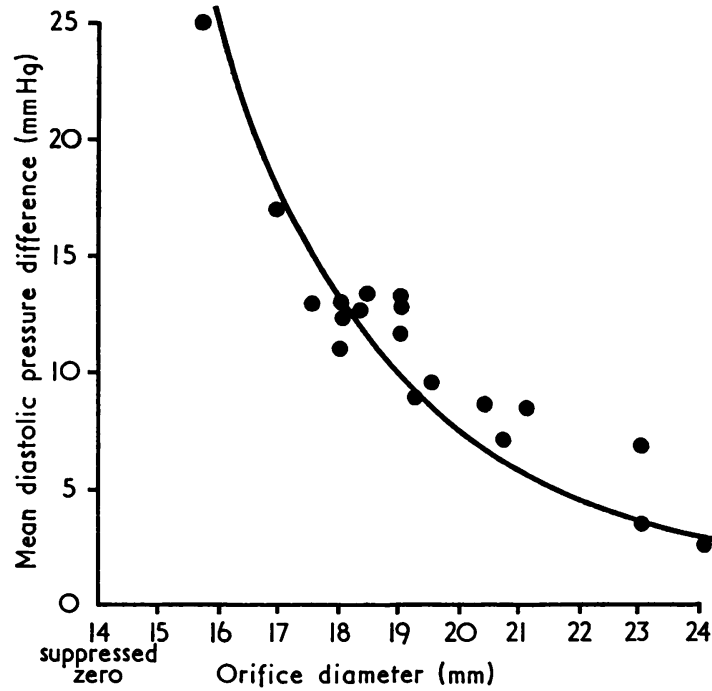

FIG. 21. Variation of mean diastolic pressure difference with orifice diameter of the prosthesis at a pulse rate of 140 per minute and a stroke volume of $58 \mathrm{ml}$.
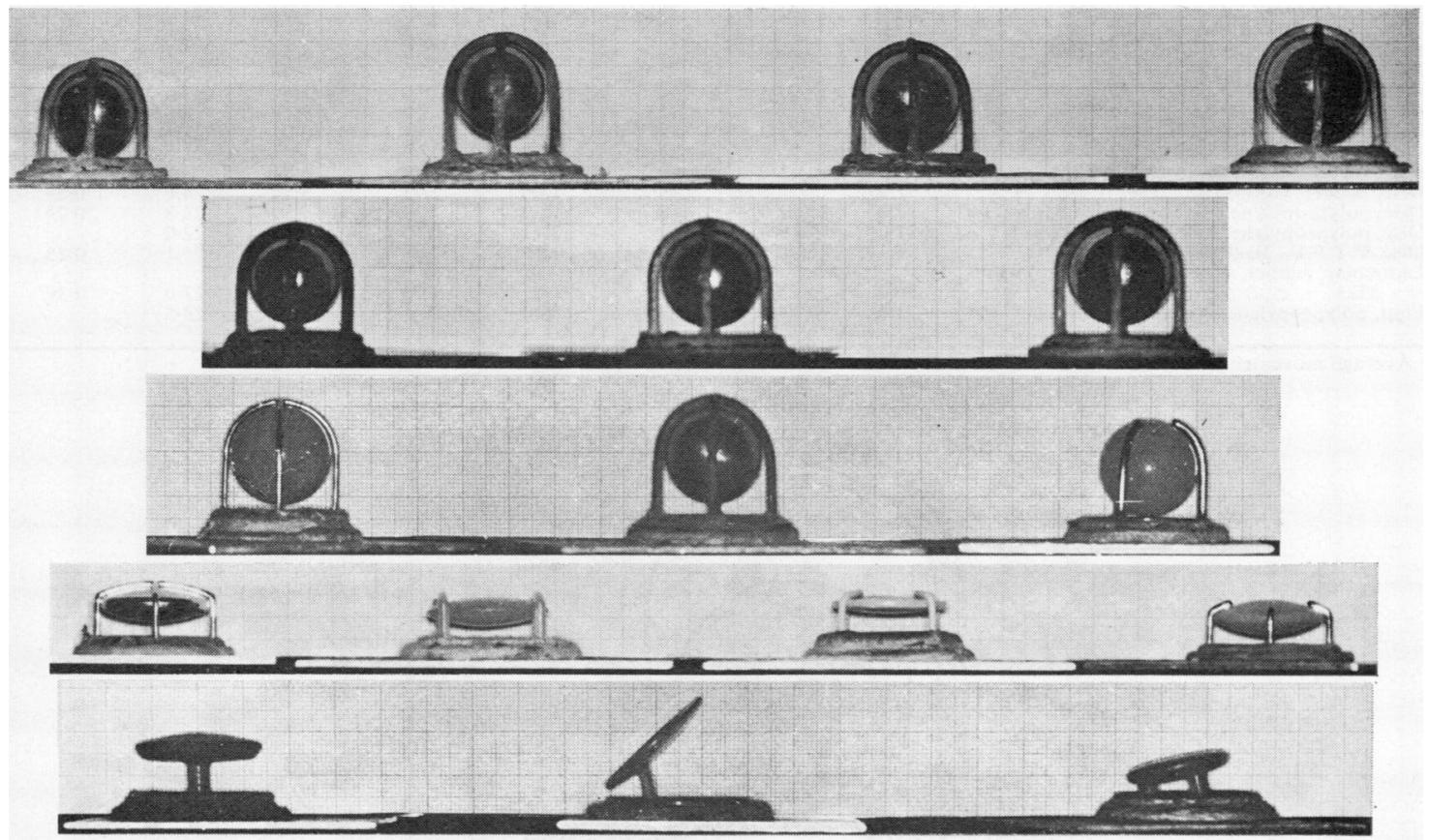

FIG. 22. A profile view of the valves. Top row, left to right: Starr-Edwards $63001 M, 2 M, 3 M, 4 M$. Second row: StarrEdwards 6310 2M, 3M, 4M. Third row: Starr-Edwards 6120/3M, Lusterlite 3, Smeloff-Cutter M7. Fourth row: StarrEdwards 6500/3M, Hufnagel 11, Beall medium, Cooley-Bloodwell-Cutter 31. Bottom row: University of Cape Town M23, Abrams-Lucas, Hammersmith-Portex P1. 


\section{RESULTS}

Throughout the programme the Starr-Edwards model $6300 / 3 \mathrm{M}$ valve was used as a standard, i.e., before each series of experiments this valve was retested to see if the results obtained were consistent with previous results. Typical variations were $\pm 0.5 \mathrm{mmHg}$ or $\pm 10 \%$, whichever was the greater for pressure difference measurements and $\pm 1 \%$ for incompetence measurements (see Wright and Temple, 1971).

The results of the mean diastolic pressure difference and incompetence tests on individual valves are shown in Figures 1 to 17 . Each graph shows variation of both mean diastolic pressure difference and percentage incompetence with pulse rate, at stroke volumes of 58, 126, and 184 $\mathrm{ml}$ per stroke. Figure 18 compares the mean diastolic pressure difference and incompetence levels of sizes 1 to 4 Starr-Edwards 6300 valve, Fig. 19 those of the model 6310 sizes 2 to 4 , and Fig. 20 compares the mean diastolic pressure differences of all prostheses at a stroke volume of $58 \mathrm{ml}$. The relationship between orifice diameter and mean diastolic pressure difference at a pulse rate of 140 per minute and a stroke volume of $58 \mathrm{ml}$ (a simulated cardiac output of 8 litres $/ \mathrm{min}$ ) is shown (Fig. 21).

The principal dimensions of the valves are given in Table 1 (Fig. 22).

A ciné film taken of the valve actions revealed: (a) In all of the ball valves which were observed,

T A B L E I

PRINCIPAL DIMENSIONS OF VALVES TESTED

\begin{tabular}{|c|c|c|c|c|c|c|c|c|}
\hline Valve Type, Make and Model & $\begin{array}{l}\text { Annulus } \\
\text { Diameter } \\
(\mathrm{mm})\end{array}$ & $\begin{array}{l}\text { Orifice } \\
\text { Diameter } \\
(\mathrm{mm})\end{array}$ & $\begin{array}{l}\text { Closed } \\
\text { Length } \\
(\mathrm{mm})\end{array}$ & $\begin{array}{c}\text { Length } \\
(\mathrm{mm})\end{array}$ & $\begin{array}{l}\text { Width } \\
\text { (mm) }\end{array}$ & $\underset{\begin{array}{c}\text { Poppet } \\
\text { Movement } \\
(\mathrm{mm})\end{array}}{\mid}$ & $\begin{array}{l}\text { Poppet } \\
\text { Diameter } \\
(\mathrm{mm})\end{array}$ & $\begin{array}{c}\text { Ratio of } \\
\text { Poppet } \\
\text { Movement } \\
\text { to Orifice } \\
\text { Diameter }\end{array}$ \\
\hline $\begin{array}{l}\text { Ball, metal, Starr-Edwards } 6300 / 1 \mathrm{M} \\
\text { Ball, metal, Starr-Edwards } 6300 / 2 \mathrm{M} \\
\text { Ball, metal, Starr-Edwards } 6300 / 3 \mathrm{M} \\
\text { Ball, metal, Starr-Edwards } 6300 / 4 \mathrm{M} \\
\text { Ball, rubber, Starr-Edwards } 6120 / 3 \mathrm{M} \\
\text { Ball, metal, Lusterlite Size } 3 \\
\text { Ball, rubber, Smeloff-Cutter } \mathrm{M} 7 \\
\text { Ball, metal, Starr-Edwards } 6310 / 2 \mathrm{M} \\
\text { Ball, metal, Starr-Edwards } 6310 / 3 \mathrm{M} \\
\text { Ball, metal, Starr-Edwards } 6310 / 4 \mathrm{M} \\
\text { Disc, metal, Starr-Edwards } 6500 / 3 \mathrm{M} \\
\text { Disc, rubber, Cooley-Bloodwell-Cutter } 31 \\
\text { Disc, polypropylene, Hufnagel discoid Size } 11 \\
\text { Disc, polypropylene, Portex-Hammersmith } 1 \\
\text { Disc, P.T.F.E., Beall medium } \\
\text { Lenticular. }\end{array}$ & $\begin{array}{l}26 \cdot 0 \\
28 \cdot 0 \\
30 \cdot 0 \\
32 \cdot 0 \\
30 \cdot 0 \\
30 \cdot 0 \\
30 \cdot 0 \\
28 \cdot 5 \\
30 \cdot 5 \\
32 \cdot 5 \\
30 \cdot 0 \\
31 \cdot 0 \\
33 \cdot 0 \\
31 \cdot 0 \\
31 \cdot 7\end{array}$ & $\begin{array}{l}15 \cdot 8 \\
17 \cdot 0 \\
18 \cdot 3 \\
19 \cdot 5 \\
19 \cdot 0 \\
17 \cdot 5 \\
21 \cdot 1 \\
18 \cdot 0 \\
19 \cdot 3 \\
20 \cdot 8 \\
18 \cdot 0 \\
19 \cdot 0 \\
23 \cdot 0 \\
19 \cdot 0 \\
20 \cdot 4\end{array}$ & $\begin{array}{r}16 \cdot 5 \\
18 \cdot 0 \\
18 \cdot 3 \\
20 \cdot 5 \\
20 \cdot 8 \\
20 \cdot 0 \\
12 \cdot 7 \\
17 \cdot 6 \\
19 \cdot 8 \\
21 \cdot 0 \\
6 \cdot 2 \\
8 \cdot 2 \\
8 \cdot 7 \\
9 \cdot 5 \\
9 \cdot 3\end{array}$ & $\begin{array}{l}26.0 \\
31.0 \\
29.7 \\
32.3 \\
30.8 \\
32.0 \\
26.7 \\
29.5 \\
30.0 \\
32.5 \\
13.2 \\
13.6 \\
15.0 \\
17.7 \\
15.5\end{array}$ & $\begin{array}{l}23.5 \\
25 \cdot 0 \\
26.0 \\
27.5 \\
25.0 \\
26.0 \\
26.0 \\
25 \cdot 0 \\
26.4 \\
27 \cdot 0 \\
26.9 \\
27.5 \\
31.8 \\
22.0 \\
29.8\end{array}$ & $\begin{array}{r}7.0 \\
10.8 \\
9.0 \\
9.6 \\
8.5 \\
10.0 \\
13.6 \\
10.1 \\
10.0 \\
11.0 \\
5.5 \\
5.5 \\
5.5 \\
10.11 \\
5.0\end{array}$ & $\begin{array}{l}18 \cdot 4 \\
19 \cdot 8 \\
21 \cdot 2 \\
22 \cdot 6 \\
21 \cdot 7 \\
21 \cdot 0 \\
21 \cdot 0 \\
19 \cdot 8 \\
21 \cdot 3 \\
22 \cdot 5 \\
23 \cdot 8 \\
24 \cdot 0 \\
26 \cdot 8 \\
22 \cdot 0 \\
25 \cdot 1\end{array}$ & $\begin{array}{l}0.44 \\
0.64 \\
0.49 \\
0.49 \\
0.45 \\
0.57 \\
0.64 \\
0.56 \\
0.52 \\
0.53 \\
0.31 \\
0.29 \\
0.24 \\
\\
0.25\end{array}$ \\
\hline $\begin{array}{l}\text { Lenticular, rubber, University of Cape } 1 \text { own } \\
\text { M23 } \\
\text { Flap, polypropylene, Abrams-Lucas }\end{array}$ & $\begin{array}{l}30 \cdot 0 \\
32 \cdot 0\end{array}$ & $\begin{array}{l}23 \cdot 0 \\
24 \cdot 0\end{array}$ & $\begin{array}{l}9 \cdot 5 \\
6 \cdot 5\end{array}$ & $\begin{array}{l}18 \cdot 7 \\
29 \cdot 0\end{array}$ & $\begin{array}{l}27 \cdot 0 \\
28 \cdot 5\end{array}$ & $\begin{array}{c}9 \cdot 0 \\
15 \cdot 5^{1}\end{array}$ & $\begin{array}{l}27 \cdot 0 \\
28 \cdot 5\end{array}$ & $0 \cdot 39$ \\
\hline
\end{tabular}

Average movement.

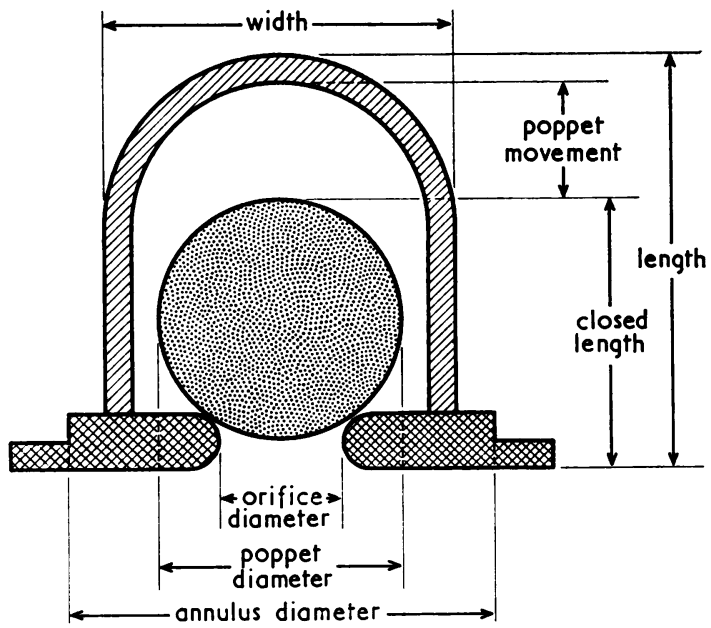


the ball bounced several times off the cage apex on opening and oscillated from side to side in the cage. In the Starr-Edwards $6300 / 3 \mathrm{M}$ and $6120 / 3 \mathrm{M}$ this bounce was approximately $25 \%$ of the total ball travel. Only in the Starr-Edwards $6120 / 3 \mathrm{M}$ did the ball bounce on closure. Dye injection in the valve orifice during diastole revealed the formation of a vortex in the proximity of the ball cage (Fig. 23).

(b) Tilting of the disc during the opening and closing sequence was common to all the disc valves and is illustrated in Fig. 24 which shows

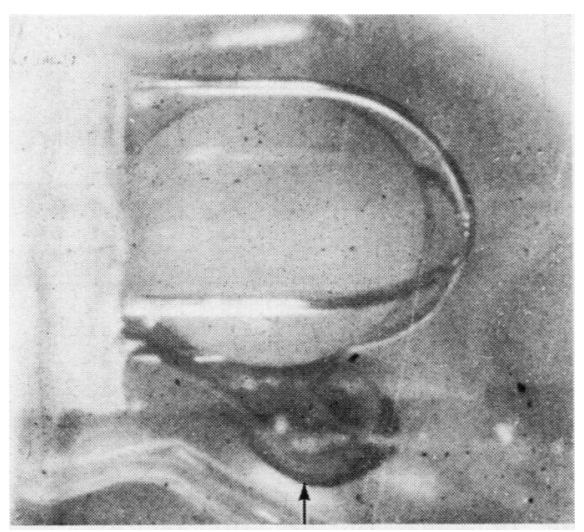

FIG. 23. Vortex formation in proximity of the cage of the Starr-Edwards $6120 / 3 M$ valve.

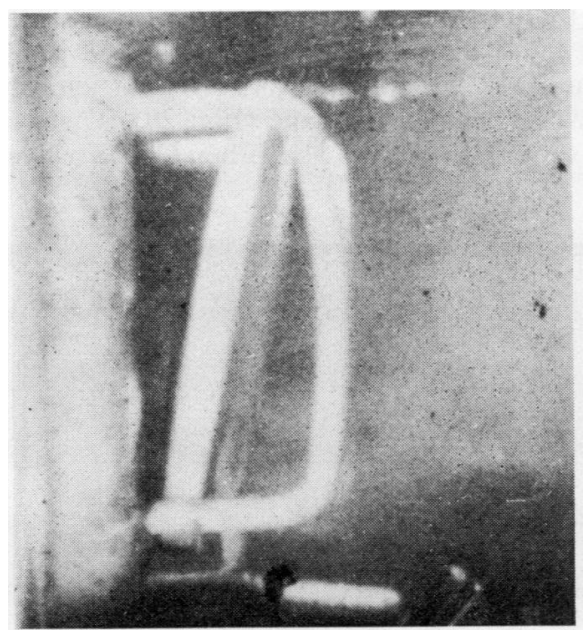

FIG. 24. Tilting of the disc of the Beall valve during opening and closure. a lateral view of the Beall valve. Eddy formation took place just distal to the disc of these valves.

(c) The University of Cape Town valve showed random angulation during opening (Fig. 25).

The mean diastolic flow velocities through certain valves measured with a hot film anemometer are shown (Fig. 26) and a comparison of the turbulence spectrum up to $1 \mathrm{kHz}$ is shown in Fig. 27 after standardizing the results at $4 \mathrm{~Hz}$.

Manufacturing quality and design features were examined and opinions formed.

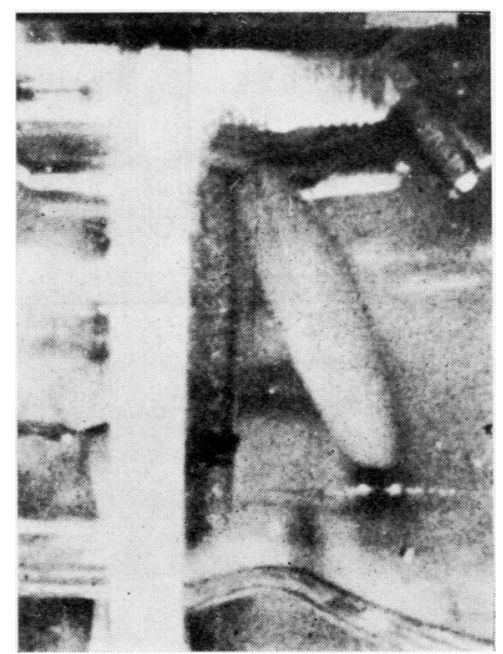

FIG. 25. Angulation of lenticular member of the University of Cape Town valve.

STARR-EDWARDS VALVES The Starr-Edwards valves appeared to be well made and were of high quality. A disadvantage was that the woven material which was used as a covering of the model 6300 frayed if it was cut. The four struts (of the model 6300) were not designed to be joined at the apex of the cage and this did allow some distortion of the cage if excessive force was applied to it. The valves were very well packed and could be sterilized, by autoclaving or ethylene oxide gas, without being removed from the container.

LUSTERLITE VALVES The Lusterlite valve had a material covering that did not fray when cut, and the cage top was joined. The standard of sewing round the sewing ring was not as good as in the Starr-Edwards valves. The polished finish of the titanium ball was not very good, and the ball left 

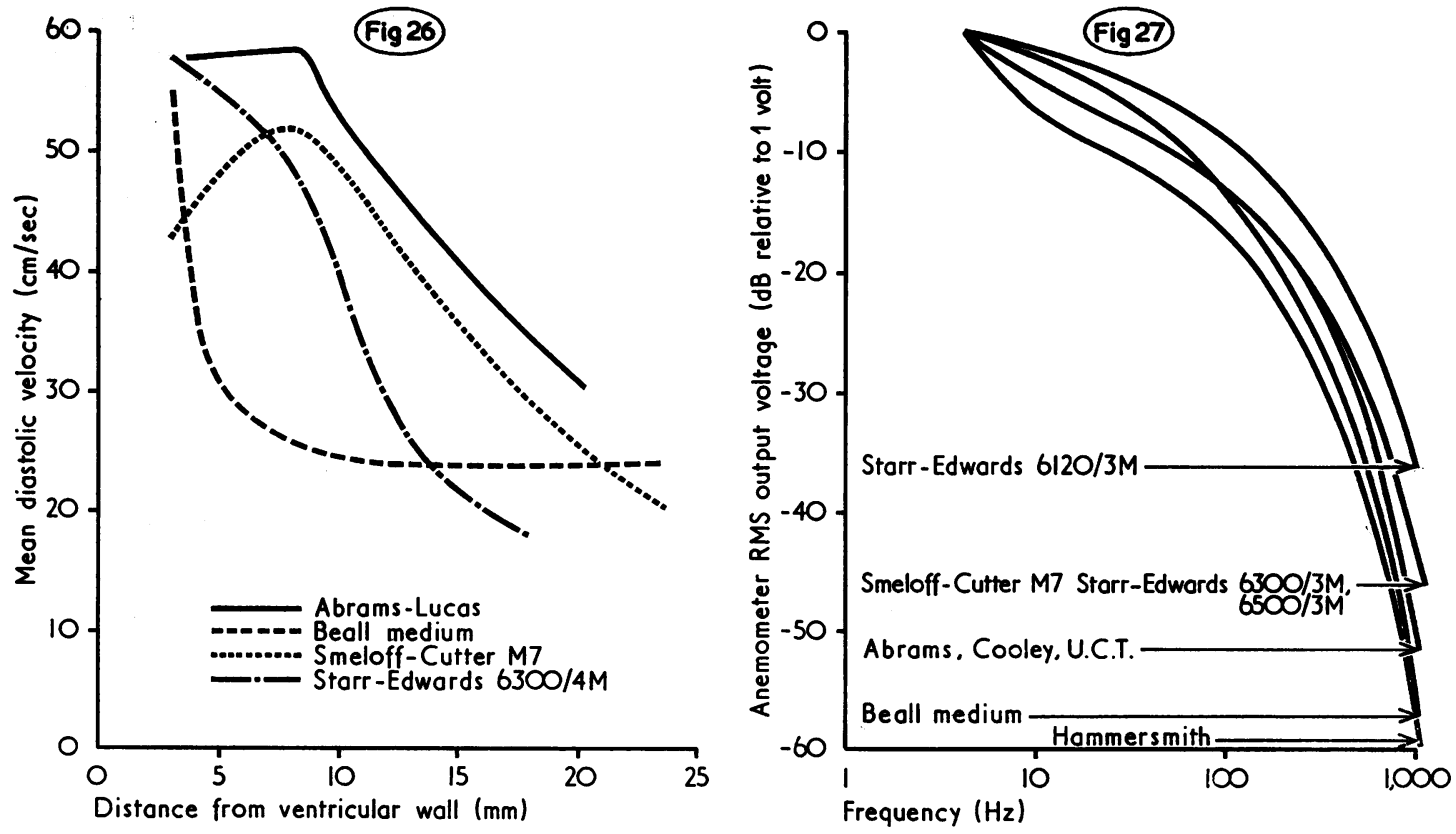

FIG. 26. Mean diastolic velocity profile distal to some prostheses. Pulse rate $100 /$ min and stroke volume $58 \mathrm{ml}$.

FIG. 27. Comparison of turbulence spectrum generated by the prostheses at a pulse rate of $80 /$ min and a stroke volume of $58 \mathrm{ml}$.

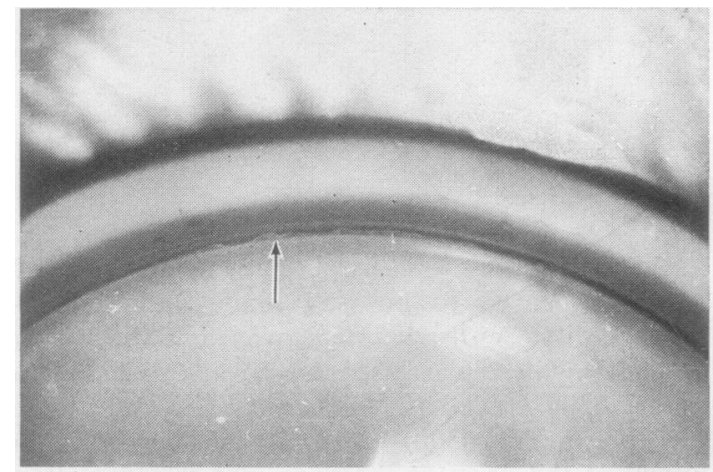

FIG, 28. Moulding flash round the ball of the SmeloffCutter M23 prosthesis.

a black ring round the cloth-covered orifice. The valve was supplied in a translucent screw-top plastic container.

SMELOFF-CUTTER VALVE The rubber ball on this valve had not been properly 'defrazed', or finished off. Figure 28 shows the ragged 'flash' left round the mould split line of the ball. The 'flash' might become detached during clinical use and cause embolus, or form a site for thrombus deposit. The valve was well packed but could not be sterilized without being removed from its container.

COOLEY-BLOODWELL-CUTTER VALVE Flash was also present on this Cutter valve round the periphery of the disc. The design was such that jamming of the valve could take place (Fig. 29). The packing was similar to that in the other Cutter valve.

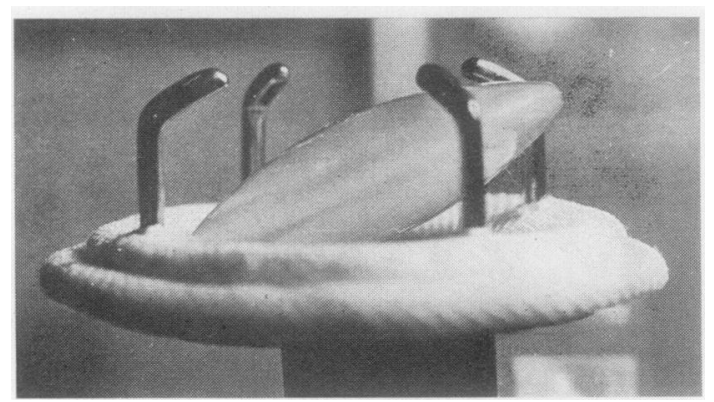

FIG. 29. Jamming position of the Cooley-Bloodwell Cutter 31 prosthesis. 
hufNagel VALVE This valve suffered from several defects:

(a) the seat was hairy ;

(b) the cage legs had numerous bubbles entrained during moulding;

(c) the cage legs had sharp corners on the inside bend of the cage. These 'unradiused' or sharp corners produce high local stresses which can lead to fracture ;

(d) the design was such that the disc could jam open.

The legs of the valve fractured during testing; the defects are shown (Fig. 30). This valve was supplied in a plastic bag; on one side of the bag was the instruction to sterilize by autoclaving, on the other side of the bag a stick-on label instructing the user not to autoclave but to sterilize chemically.

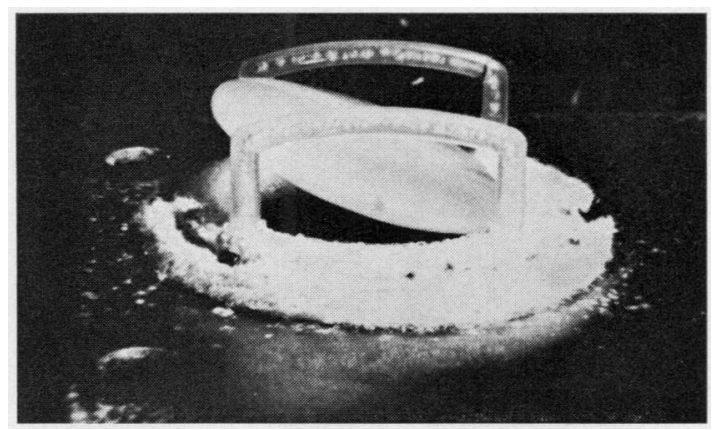

FIG. 30. The faulty Hufnagel prosthesis.

HAMMERSMITH-PORTEX VALVE The surface finish of the valve was poor and the seat hairy (Fig. $31)$. When the valve was held in the closed position a gap existed around part of the disc periphery and the orifice. The valve was packed in a transparent plastic container and a cardboard box. The valve could be sterilized without being removed from the plastic container, but the two halves of the container were not fixed together.

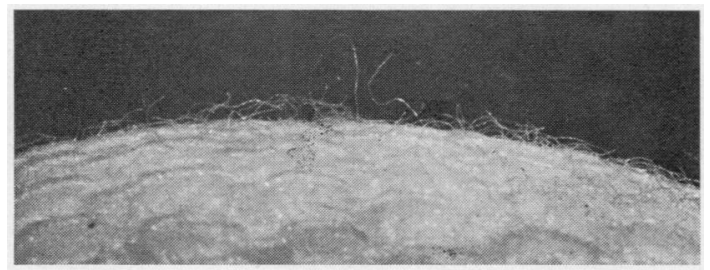

FIG. 31. Portion of sewing ring of Hammersmith-Portex prosthesis.
UNIVERSITY OF CAPE TOWN VALVE The silicone rubber poppet had flash round the split line. Several valves were examined and some showed signs of surface fatigue of the single arm strut before use. It was concluded that this fatigue had occurred during the mechanical polishing operation. The valve was packed in a cellophane bag.

BEALl VALVE The valve was not new at the start of the tests. At the conclusion of testing the surface of the soft P.T.F.E. disc was marked with scratches.

ABRAMS-LUCAS VALVE This valve, which was supplied for testing only, was not finished to the same standard as those valves used clinically. On this sample there was moulding flash present on the valve. The sewing ring, which was of polypropylene felt moulded into the valve orifice, had a high resistance to needle penetration and was sewn onto the mounting plate with difficulty. The principal defect of the valve was the ease with which it could be taken apart.

\section{DISCUSSION OF RESULTS}

MEAN DIASTOLIC PRESSURE DIFFERENCE The mean diastolic pressure difference results clearly show considerable variations between the different prostheses tested. The valves can be divided arbitrarily into four groups.

Valves with very high pressure differences The Starr-Edwards $63001 \mathrm{M}$ and $2 \mathrm{M}$ had very high pressure differences: 3.2 and $4.4 \mathrm{mmHg}$ at pulse rates of $60 / \mathrm{min}$ rising to 16.8 and $24.9 \mathrm{mmHg}$ at pulse rates of $140 / \mathrm{min}$.

Valves with high pressure differences The CooleyBloodwell-Cutter 31 disc, the Starr-Edwards $6300 / 3 \mathrm{M}, 6310 / 2 \mathrm{M}$, and $6120 / 3 \mathrm{M}$ ball valves, and the Lusterlite ball valve had a pressure difference of $1.9-2.7 \mathrm{mmHg}$ at a pulse rate of $60 / \mathrm{min}$, rising to $11 \cdot 0-13 \cdot 3 \mathrm{mmHg}$ at a pulse rate of $140 / \mathrm{min}$.

Valves with moderate pressure differences. The Starr-Edwards $6300 / 4 M, 6310 / 3 M, 6310 / 4 M$, the Smeloff-Cutter M7, Beall medium, and the Hufnagel 11 had pressure differences in the range $0.9-2.0 \mathrm{mmHg}$ and $6.4-9.3 \mathrm{mmHg}$ over the same range of pulse rates.

Valves with lowest pressure differences The University of Cape Town valve had a pressure difference of $3.3 \mathrm{mmHg}$ at $140 / \mathrm{min}$ and the AbramsLucas flap valve $2 \cdot 1 \mathrm{mmHg}$ at $140 / \mathrm{min}$.

These comparisons were made at a stroke volume of $58 \mathrm{ml}$. 
The relation between mean diastolic pressure difference and orifice diameter is shown (Fig. 21) at a stroke volume of $58 \mathrm{ml}$ and a pulse rate of $140 /$ minute. This relation may be expressed by

$$
\overline{\mathbf{P}_{\mathrm{d}}}=\frac{1.05 \times 10^{8}}{\mathrm{D}^{5.5}}
$$

where $\overline{\mathbf{P}}_{\mathrm{d}}=$ mean diastolic pressure difference $(\mathrm{mmHg})$ at a pulse rate of $140 / \mathrm{min}$ and a stroke volume of $58 \mathrm{ml}$ and $\mathrm{D}=$ orifice diameter $(\mathrm{mm})$.

This graph does not imply that valve design has no influence upon mean diastolic pressure difference, because obviously a change in poppet movement would influence this. However, for the valves tested it is clear that the orifice diameter has an important influence on the pressure difference. Therefore, a small reduction of this diameter due to tissue ingrowth could be expected to cause a relatively large increase in pressure difference, especially in prostheses with a small orifice. This is confirmed in Fig. 32 which shows the effect of tissue ingrowth on the pressure difference of a Starr-Edwards $6300 / 2 M$ valve removed from a patient because of restenosis. Most of the valves tested had a cloth-covered orifice actually to encourage tissue ingrowth, and it follows that these valves would probably show some increased pressure differences in clinical use if tissue were deposited in the orifice.

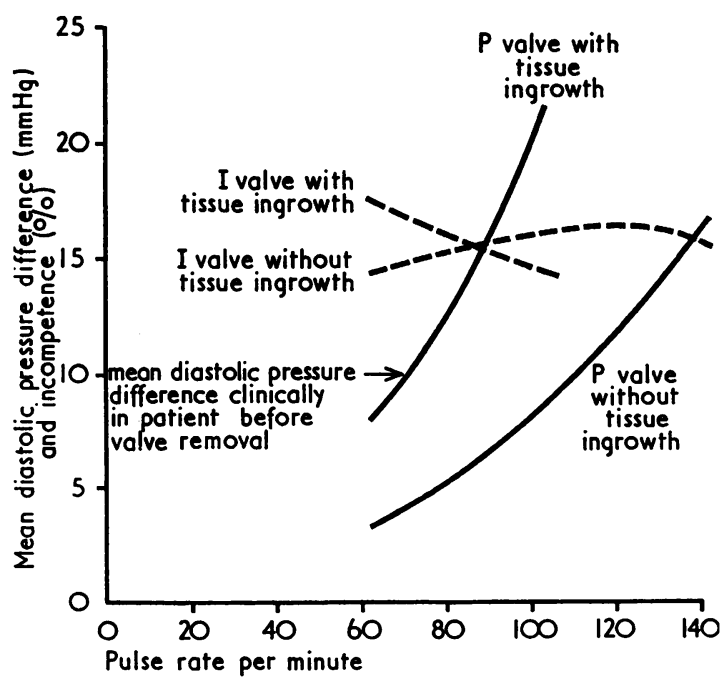

FIG. 32. Comparison of mean diastolic pressure differences and percentage incompetence of Starr-Edwards $6300 / 2 M$ prosthesis between a valve with and without tissue ingrowth.
The Starr-Edwards rubber-balled valve model $\overrightarrow{\vec{F}}$ 6120 needed a transient pressure gradient of about $\overline{0}$ $30 \mathrm{mmHg}$ to unseat the ball from its orifice (Fig. 듬 33). This was because the ball (being elastic) was $\overline{\bar{m}}$ squeezed into its seat during systole. The ball $\mathbb{\Phi}$ then required a high pressure difference to overcome the friction which existed between it and ${ }^{\circ}$ the orifice before opening could occur.

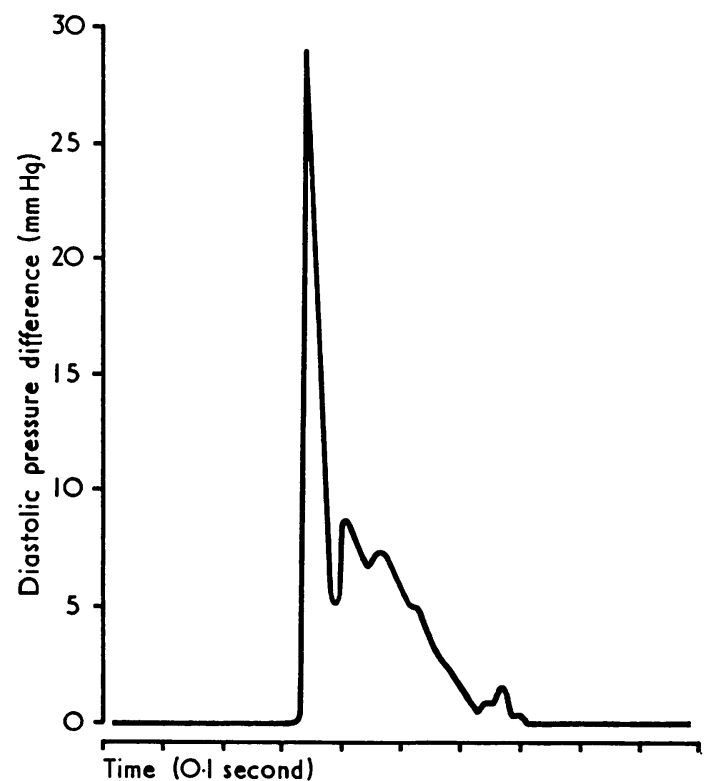

5IG. 33. Transient opening pressure of Starr-Edwards $6120 / 3 M$ prosthesis.

INCOMPETENCE TESTS Valves may be categorized into three different arbitrary incompetence levels at the lowest stroke volume:

(a) The Starr-Edwards $6300 / 2 \mathrm{M}$ had an in- $D$ competence level between $14.5 \%$ and $16.5 \%$ when new, but tissue ingrowth varied this to between $\vec{N}$ $17.8 \%$ and $14.9 \%$ later. The Smeloff-Cutter valve had incompetence levels which ranged from $\tilde{o}$ $11.0 \%$ to $16.2 \%$.

(b) Valves with moderate incompetence were 0 the remaining ball valves, the Abrams flap valve, 0 the U.C.T., and the Starr-Edwards $6500 / 3 \mathrm{M}$ disc. $\frac{\bar{D}}{\Phi}$ This group had incompetences in the range of $\stackrel{?}{?}$ $7 \cdot 9 \%$ to $13 \cdot 4 \%$.

(c) The Cooley, Hammersmith, Beall, and Hufnagel disc valves had the lowest incompetence levels of $5 \cdot 1 \%$ to $8.8 \%$.

All valves tested showed a reduction of in- $\frac{a}{\sigma}$ competence as the stroke volume was increased. 
The ball valves, which were less competent than a majority of the disc valves, showed increased incompetence with relative increased poppet movement. Table I shows the ratio of poppet movement to orifice diameter. The disc valves had ratios in the range $0.24-0.39$ and were more competent than the ball valves, a majority of which had ratios in the range $0.44-0.55$. The two ball valves with the highest incompetence levels, the Smeloff-Cutter and the Starr-Edwards 6300/ $2 \mathrm{M}$, had ratios of 0.64 , and another ball valve with a high incompetence level, the Lusterlite, had a ratio of 0.57 . With the exception of the Hufnagel valve (which had a comparatively short poppet movement) valves with larger orifices had increased incompetence levels. This is typified by a comparison between the Starr-Edwards 6300/ $4 \mathrm{M}$ and $6300 / 3 \mathrm{M}$. It is the retrograde flow through a prosthetic valve which causes the valve to close. Valves with a low forward pressure difference usually also display a low reverse pressure difference when open and so require an increased retrograde flow rate in order to cause closure. However, in the flap valve a large ventricular vortex probably assisted in valve closure.

Effect of incompetence on mean diastolic pressure difference In clinical use, the effect of incompetence of a prosthesis will be to cause the

T A B L E I I HYDRAULIC MERITS

\begin{tabular}{|c|c|c|}
\hline Valve & $\begin{array}{c}\text { Mean Diastolic } \\
\text { Pressure } \\
\text { Difference } \\
\text { (mmHg) at } \\
\text { Cardiac Output } \\
\text { of } 4 \cdot 51 / \mathrm{min} \text {, Pulse } \\
\text { Rate } 80 / \mathrm{min}\end{array}$ & $\begin{array}{c}\text { Cardiac Output } \\
\text { (1/min) at Mean } \\
\text { Diastolic } \\
\text { Pressure } \\
\text { Difference } \\
\text { of } 20 \mathrm{mmHg} \text {, } \\
\text { Pulse Rate } \\
140 / \mathrm{min}\end{array}$ \\
\hline $\begin{array}{l}\text { Abrams-Lucas } \\
\text { U.C.T. M23 }\end{array}$ & $\begin{array}{c}\text { No significant } \\
\text { stenosis } \\
0.6 \\
1.4\end{array}$ & $\begin{array}{l}19 \cdot 7 \\
17 \cdot 6\end{array}$ \\
\hline $\begin{array}{l}\text { Starr-Edwards } 6310 / 4 \mathrm{M} \\
\text { Smeloff-Cutter M7 } \\
\text { Starr-Edwards } 6310 / 3 \mathrm{M} \\
\text { Starr-Edwards } 6300 / 4 \mathrm{M} \\
\text { Beall medium } \\
\text { Cooley-Bloodwell-Cutter } 31\end{array}$ & $\begin{array}{c}\text { Mild stenosis } \\
2 \cdot 4 \\
3 \cdot 0 \\
3 \cdot 1 \\
3 \cdot 2 \\
3 \cdot 7 \\
3 \cdot 8\end{array}$ & $\begin{array}{r}14 \cdot 7 \\
14 \cdot 2 \\
11 \cdot 3 \\
11 \cdot 8 \\
12 \cdot 4 \\
9 \cdot 9\end{array}$ \\
\hline $\begin{array}{l}\text { Starr-Edwards } 6310 / 2 \mathrm{M} \\
\text { Starr-Edwards } 6300 / 3 \mathrm{M} \\
\text { Starr-Edwards } 6500 / 3 \mathrm{M} \\
\text { Lusterlite Size } 3 \\
\text { Starr-Edwards } 6120 / 3 \mathrm{M}\end{array}$ & $\begin{array}{c}\text { Mild/moderate } \\
\text { stenosis } \\
4 \cdot 0 \\
4 \cdot 4 \\
4 \cdot 5 \\
4 \cdot 6 \\
4 \cdot 8\end{array}$ & $\begin{array}{r}10 \cdot 9 \\
10 \cdot 0 \\
10 \cdot 5 \\
9 \cdot 6 \\
11 \cdot 3\end{array}$ \\
\hline $\begin{array}{l}\text { Hammersmith-Portex P1 } \\
\text { Starr-Edwairds 6300/2M } \\
\text { Starr-Edwards } 6300 / 1 \mathrm{M}\end{array}$ & $\begin{array}{c}\text { Moderate stenosis } \\
5 \cdot 1 \\
6 \cdot 5 \\
8 \cdot 5\end{array}$ & $\begin{array}{l}9 \cdot 4 \\
8 \cdot 2 \\
6 \cdot 8\end{array}$ \\
\hline
\end{tabular}

The Hufnagel valve fractured before the tests were completed. heart to increase its stroke volume in order to achieve the cardiac output necessary to meet metabolic requirements. This increase in volume pumped would also increase the diastolic pressure difference across the prosthesis without contributing to cardiac output. In order to emphasize this effect Table II has been drawn up and shows the mean diastolic pressure difference at a cardiac output of $4.51 / \mathrm{min}$ and a pulse rate of $80 /$ minute. Also shown is the cardiac output at a pulse rate of $140 / \mathrm{min}$ which would produce a mean diastolic pressure difference of $20 \mathrm{mmHg}$. The former represents the mean diastolic pressure difference at cardiac resting (near basal) rate, and the latter gives a measure (a rather arbitrary one) of the likely limits of exercise tolerance of a patient who had that particular prosthesis implanted.

It can be seen that:

(a) the U.C.T. M23 and the Abrams-Lucas would produce no significant stenosis;

(b) the Smeloff-Cutter M7, Beall medium, StarrEdwards $6300 / 4 \mathrm{M}, 6310 / 3 \mathrm{M}, 6310 / 4 \mathrm{M}$, and Coolev-Bloodwell-Cutter 31 would produce a mild stenosis ;

(c) the Starr-Edwards 6120/3M, 6300/3M, 6500/ $3 \mathrm{M}, 6310 / 2 \mathrm{M}$, and Lusterlite size 3 would all produce a mild/moderate stenosis ;

(d) the Starr-Edwards $63001 \mathrm{M}$ and $2 \mathrm{M}$ and Hammersmith Portex valve would produce moderate stenosis ;

(e) the U.C.T. M23 and Abrams-Lucas valves both allow a good cardiac output under extreme exercise conditions ;

( $f$ ) the other valves, with the exception of the Starr-Edwards $63001 \mathrm{M}$ and $2 \mathrm{M}$ model, allow moderate cardiac outputs under exercise.

Mechanical movements of valves visualized by cinephotography The claim that the ball of ball valves rolled rather than slid along the cage struts was not verified, and as the ball oscillated some sliding was inevitable.

All the disc valves showed tilting during the opening or closing phase (in the Hammersmith valve this was a design feature). No rotation of the discs was observed. The tilting action produced is probably caused by friction and, coupled to the absence of disc rotation, would probably lead to localized wear of the discs. Beall et al. (1969) reported wear of the disc in the Beall valve and wear has occurred in other disc valves not tested here (Paton, 1969; Vasko, 1968 ; Hughes and Carey, 1969). The U.C.T. M13 valve showed random angular movement of the poppet which 
might cause it to hit the walls of the relaxing ventricle during early diastole.

Flow velocity measurements The anemometer measurements showed that the disc valves had a flat, low velocity profile distal to the disc, which rose steeply at the walls. The probe could not easily be placed nearer to the wall than $3 \mathrm{~mm}$ and it is in this region that maximum flow velocity must have occurred with the disc valves.

The ball valves and the flap valve had a more gently rising velocity profile, and the SmeloffCutter ball valve, with its comparatively smaller ball, had a velocity profile which reached a peak value some distance from the wall.

The Starr-Edwards rubber ball valve $6120 / 3 \mathrm{M}$ had more high frequency turbulence than other valves tested, and the Beall valve had less. It is the higher frequencies of the spectral band (the smallest eddies) which are responsible for the dissipation of energy, but these are unimportant as regards the general pattern of flow. The larger eddies serve to transfer, almost without loss, energy to the smallest eddies where the dissipation of energy or pressure loss occurs (Landau and Lifshitz, 1969).

Valve dimensions The different valve types had rather different dimensional characteristics:

(a) The closed length, which gives some measure of possible obstruction of the outflow tract of the left ventricle, ranged from 16.5 to 21.0 $\mathrm{mm}$ in conventional ball valves $(12.7 \mathrm{~mm}$ for the Smeloff-Cutter) but was only 6.2 to $9.5 \mathrm{~mm}$ in the disc valves. The Abrams-Lucas valve measured $6.0 \mathrm{~mm}$.

(b) The overall width of the ball valves varied from 23.5 to $27.5 \mathrm{~mm}$ but the disc valves were wider at 27.0 to $31.8 \mathrm{~mm}$ (an exception was the Hammersmith at $22.0 \mathrm{~mm}$ ).

(c) The maximum length of the ball valves varied from 26.0 to $32.5 \mathrm{~mm}$ while the disc valves were shorter at 13.2 to $18.7 \mathrm{~mm}$. The AbramsLucas valve had a total length of $29 \mathrm{~mm}$ when open.

It can, therefore, be seen that the ball valves were longer, would be likely to offer more aortic obstruction, but were narrower than the disc valves.

The Starr-Edwards 6300 group of valves showed a steady progression of dimensions from size 1 to 4 with the exception of the size 2 valve. The cage length and poppet movement was longer than the size 3 valve. It was this disproportionate poppet $\stackrel{\overrightarrow{\bar{O}}}{+}$ movement that was responsible for the high incompetence characteristic of this valve. The cage width was only $1.5 \mathrm{~mm}$ less than the size 3 .

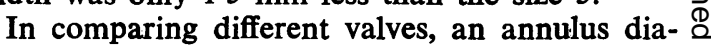
meter of $30-31 \mathrm{~mm}$ was chosen. It is often this annulus size which is selected by the surgeon to $\vec{A}$ fit into the mitral ring. Only the Cooley-Bloodwell-Cutter used the annulus diameter as the $\vec{\omega}$ size number of the valve prosthesis. Some manu- $O$ facturers did not list this dimension in their $\overrightarrow{\vec{x}}$ literature. If manufacturers used the annulus diameter of the valve to indicate the size it $\dot{\omega}$ would make selection easier.

\section{MANUFACTURING STANDARD}

Considering the vital function that the valve prostheses have to perform, and their high costs coupled to the cost and dangers of operation and re-operation, the standard of workmanship of some valves was poor. The following suggestions could be directed at the manufacturers:

(a) The two Cutter valves could have had the $\frac{{ }_{0}^{\circ}}{\mathbb{D}}$ moulding flash removed.

(b) The Lusterlite valve could have been better finished.

(c) The Hufnagel valve was poorly made and generally mechanically unsatisfactory.

(d) The Hammersmith-Portex valve was poorly finished ; it also had a hairy sewing ring, and ${ }_{-}^{x}$ moulding inaccuracies allowed leakage to take place when the valve was closed.

(e) The University of Cape Town valve had gross flash round the split line of the silicono rubber poppet. If parts of this flash were worn off they could cause embolus. The? method of polishing the orifice and strut required reviewing.

The Starr-Edwards valves were the only ones to be packed in a way that eliminated handling $\omega$ before sterilization: packing by other manu facturers was not satisfactory. It would be ano advantage if valves were pre-sterilized.

The Beall valve was not new when obtained? and comments concerning its manufacturing ${ }_{-}$ standard and packing cannot therefore be given. The valve appeared to have been well made.

Since we tested just one example of each valve,, $\mathbb{D}$ it seems only fair to say that others of the same type might not have had the same defects. 


\section{DESIGN CONSIDERATIONS AND DEFECTS}

Some of the valves had design weaknesses, serious in some cases:

(a) The Starr-Edwards valves model 6300 did not have the cage joined at the apex, and were not covered with a non-fraying cloth. The comment about the cloth covering also applies to the disc valve and the $6120 / 3 \mathrm{M}$ rubber-balled valve. The Starr-Edwards $6300 / 2 \mathrm{M}$ had a longer cage length and a greater poppet movement than the size 3 valve. The cage width was only $1.5 \mathrm{~mm}$ less and the closed length only $0.3 \mathrm{~mm}$ less than the $3 \mathrm{M}$. Its flow performance was, however, much inferior to the $3 \mathrm{M}$. The high poppet movement made the incompetence greater, and the small orifice made the valve very sensitive to restenosis due to tissue ingrowth.

(b) The Lusterlite had a smaller orifice and a rather large poppet movement compared with the $6300 / 3 \mathrm{M}$ Starr-Edwards valve. Its dimensions were not much different from the $6300 / 4 \mathrm{M}$ Starr-Edwards valve, but it could well suffer from restenosis in the same manner as the $6300 / 2 \mathrm{M}$ Starr-Edwards.

(c) The incompetence of the Smeloff-Cutter was found to vary with the fluid temperature. At $20^{\circ} \mathrm{C}$ gross incompetence $(31 \%)$ occurred but this reduced to $16 \cdot 2 \%$ at $37^{\circ} \mathrm{C}$. This variation was caused by the thermal expansion of the silicon rubber ball. The diameteral seal formed by the ball in its orifice has some disadvantages. Variation of the ball dimensions (whether due to manufacturing tolerances or, more probably, change in size during use) could cause either jamming of the ball or an increased incompetence. Jamming has been reported by Cooley et al. (1966). Many cases of ball variances have occurred olinically with early Starr-Edwards aortic prostheses, and the ball dimension of the Smeloff-Cutter valve is more critical than in the Starr-Edwards. No cases of ball variance have been reported by the manufacturers, however.

(d) The design of the Cooley-Bloodwell-Cutter valve was such that the disc could jam in the open position. Jamming did not take place in rig testing but as the valve closed with the disc tilted, jamming might occur in clinical use. The use of silicon rubber as the disc material is likely to lead to the same wear of the disc that is a feature of the other disc valves using this material (Paton, 1969 ; Vasko, 1968).

(e) The Hammersmith-Portex valve could have been designed to have a larger orifice for the same size of sewing ring. (f) The flap of the Abrams-Lucas valve could easily be detached from the orifice. A modification to the legs of the flap and to the orifice lugs would rectify this. Wear of the lugs and legs has been a problem of this prosthesis (personal communication).

(g) The design of the Hufnagel valve was such as to allow the disc to jam in the open position.

Since this work was begun some prostheses have been modified and others are no longer available. The Starr-Edwards model 6300 and 6500 valves have since been replaced by models 6310 and 6520 valves respectively. The 6310 differs from the 6300 in that the primary orifice of the 6310 has been widened, the cage top is joined, and the cloth on the struts of the 6310 is one layer of polypropylene over one layer of Tefion, rather than two layers of Teflon, as in the 6300 . In addition, the sewing ring of the 6310 is composed of a composite cloth of Teflon and polypropylene.

The 6520 valve is quite different from the 6500 with the changes in design affecting the primary orifice and the disc of this low profile prosthesis. A larger orifice and a disc of ultrahigh molecular weight polyethylene with a titanium ring are important changes. The sewing ring is manufactured of composite cloth.

The model 6120 prosthesis is still available and the only change has been in the sewing ring cloth. This was formerly made of Teflon and now the cloth is a composite of Tefion and polypropylene.

The Cooley-Bloodwell-Cutter valve has been withdrawn from sale following an unfavourable report of high thromboembolic incidence (Messmer et al., 1970). The Smeloff-Cutter mitral valve is currently available for sale and basically has remained unchanged.

The Beall mitral valve prosthesis is still commercially available ; in addition, a Beall mitral valve with a thicker disc and thicker covering of Tefion on the struts is also manufactured.

The U.C.T. valve which was tested was obtained from the University of Cape Town. A similar prosthesis was subsequently manufactured by Dow Corning Ltd. Both these models have now been discontinued.

The Hufnagel discoid valve's basic design remains unchanged, although present models have increased travel space for the disc, and moulding and polishing techniques have been improved.

The Portex valve is still commercially available, so is the Lusterlite valve, but only to special order. 
The Abrams-Lucas valve which has not been commercially available is currently undergoing modifications to reduce wear, which will also make the valve more difficult to take apart.

CORRELATION BETWEEN RIG RESULTS AND CLINICAL FINDINGS

Glancy et al. (1969) reported mean diastolic pressure differences of $9.4 \mathrm{mmHg}$ obtained with cardiac catheterization in patients fitted with size 2 M Starr-Edwards 6300 (this was an interim standard which used a cloth-covered orifice and cage but a rubber ball). The values which they measured varied from 5.6 to $12.5 \mathrm{mmHg}$. These figures can be compared with the values we obtained on the rig of $5.6 \mathrm{mmHg}$ for a slightly dissimilar valve without tissue ingrowth to 12.8 $\mathrm{mmHg}$ for a valve with tissue ingrowth. Further confirmation between rig and clinical results may be seen in Fig. 28, which shows the mean diastolic pressure difference (measured at cardiac catheterization) of a patient with a Starr-Edwards $6300 / 2 \mathrm{M}$ valve which had restenosed and the characteristics of the identical valve obtained in rig tests after removal from the patient after 19 months' implantation.

The Smeloff-Cutter valve showed incompetence of $14.7 \%$ which occurred at low stroke volume and low pulse rate. Rouleau, Frye, and Ellis (1969) demonstrated clinical incompetence in seven patients with this prosthesis. The incompetence level of a prosthesis could be critical to a patient with poor cardiac function at the end of an operation when cardiopulmonary bypass has to be terminated whilst pulse rate and stroke volume could still be low.

The validity of the rig results presented here may perhaps be questioned on two counts: (1) that the use of rigid left atrium and left ventricular chambers might adversely affect the performance of a prosthesis; and (2) that the use of a sinusoidal test pulse rather than an accurate pulse reproduction might make the valves appear more incompetent and stenotic.

The problems of external pulse duplication were investigated at an early stage in our work and it became clear that the use of a dead heart was not suitable as a container in which to investigate mitral valve prostheses. We considered the use of artificial flexible atrial and ventricular cavities but chose the rigid chambers which we used because of their constancy. We felt that the shape and expansion characteristics of a flexible test chamber would vary with the characteristics of the prosthesis under investigation.
The filling characteristics of the natural heart are not sinusoidal. It must be remembered, however, that prostheses are not generally inserted into normal healthy hearts but often into those which have become hypertrophic. We argued in a previous paper (Wright and Temple, 1971) that the filling rate of the heart would be modified by the insertion of a prosthesis. This was confirmed by Folts, Young, and Rowe (1971), who demonstrated gross changes in the filling cycle of the intact canine heart when a prosthetic mitral valve was inserted. From their results one may conclude that the use of a mechanical valve prosthesis does indeed alter the flow characteristics of the heart to such an extent that simple, reproducible sine wave function such as we have adopted (Wright and Temple, 1971) is probably the best method of valve testing.

\section{CONCLUSION}

We have attempted to demonstrate that significant and useful information may be obtained by the rig testing of prostheses and that these in vitro results may serve as a guide to clinical performance.

On the basis of the results obtained we have listed (Table II) the valves in order of hydraulic merit alone.

The relation shown between valve orifice diameter and mean diastolic pressure differences, poppet movement and incompetence, flow pathway and turbulence, mode of action, and likely wear indicates that a scientific rather than an empirical approach to valve design is desirable. It is clear from the examination of some valves that design and manufacturing changes should be undertaken. In this respect, as well as in flow performance, the Starr-Edwards 6310 range of 욱 valves, sizes $2-4$, show marked advantages over $D$ the 6300 range which preceded them.

Only the Abrams-Lucas and the U.C.T. M23 N valves produced no significant stenosis. Both valves have undesirable features, however, but $\mathcal{N}$ neither is commercially available in the form $\mathrm{N}$ tested.

In the group of valves which produced mild 0 stenosis the Starr-Edwards $6310 / 4 \mathrm{M}$ combined $\stackrel{\odot}{\mathbb{D}}$ a fairly low mean diastolic pressure difference $\stackrel{\odot}{\rightarrow}$ with a reliable standard of manufacture. This 0 valve was, however, physically large and would $\stackrel{\circ}{\circ}$ probably show increased pressure difference if $\stackrel{\Omega}{\Omega}$ tissue ingrowth occurred in the primary orifice. $\stackrel{\mathbb{D}}{\mathbb{Q}}$ The Smeloff-Cutter M7 was small in size for its performance, compared to other ball valves, al- 
though its incompetence level was rather high at low pulse rates. A minor change to the ball finish would have made this prosthesis more clinically acceptable. The Starr-Edwards 6310/3M was well made but showed marked increase in mean diastolic pressure difference over the 6310/ $4 \mathrm{M}$ for only a modest reduction in physical size. The Beall medium was the most satisfactory of the disc valves tested but Blesovsky (1969) has reported haemolytic anaemia in patients with this prosthesis. The Cooley-Bloodwell-Cutter 31 is no longer available.

In our clinical practice the use of the valves which show mild/moderate or moderate stenosis (in Table II) are avoided except in exceptional circumstances.

The prostheses tested were clearly much more effective for the treatment of incompetence than stenosis. In order to produce low mean diastolic pressure differences a prosthesis should have a large orifice diameter (at least 23 or $24 \mathrm{~mm}$ ).

The authors would like to thank the British Heart Foundation for a research grant which allowed this work to be started. We also wish to acknowledge the cooperation of the Liverpool Cardiac Centre, the Liverpool Cardio-thoracic Surgical Centre, and the Department of Cardiothoracic Surgery, the General Infirmary, Leeds.

\section{REFERENCES}

Beall, A. C. (Jr.), Bloodwell, R. D., Arbegast, N. R., Liotta, D., Cooley, D. A., and DeBakey, M. E. (1969). Mitral valve replacement with dacron-covered disk prosthesis to prevent thromboembolism: clinical experience in 202 cases. In: Prosthetic Heart Valves-the Second National Conference on Prosthetic Heart Valves, edited by L. A. Brewer III, p. 319. Thomas, Springfield, Illinois.
Blesovsky, A. (1969). Experience with a disc valve prosthesis. Proc. British Cardiac Society. Brit. Heart J., 31, 796.

Cooley, D. A., Bloodwell, R. D., Beall, A. C. (Jr.), Gill, S. E., and Hallman, G. L. (1966). Total cardiac valve replacement using SCDK-Cutter prosthesis: experience with 250 consecutive patients. Ann. Surg., 164, 428.

Folts, J. D., Young, W. P., and Rowe, G. G. (1971). Phasic flow through normal and prosthetic mitral valves in unanaesthetised dogs.J. thorac. cardiovasc. Surg., 61, 235.

Glancy, D. L., O'Brien, K. P., Reis, R. L., Epstein, S. E., and Morrow, A. G. (1969). Hemodynamic studies in patients with $2 \mathrm{M}$ and $3 \mathrm{M}$ Starr-Edwards prostheses. Circulation, 39, suppl. 1, 1-113.

Hughes, R. K., and Carey, J. S. (1969). Experience with the Kay-Shiley mitral valve. In: Prosthetic Heart Valves, edited by L. A. Brewer, p. 587. Thomas, Springfield, Illinois.

Kalke, B., Korns, M. E., Goott, B., Lillehei, C. W., and Edwards, J. E. (1969). Engagement of ventricular myocardium by open-cage atrioventricular valvular prosthesis. J. thorac. cardiovasc. Surg., 58, 92.

Landau, L. D., and Lifshitz, E. M. (1969). Fluid Mechanics, p. 119. Pergamon, Oxford.

Messmer, B. J., Okies, J. E., Hallman, G. L., Bloodwell, R. D., and Cooley, D. A. (1970). Clinical experience with a new discoid prosthesis for mitral valve replacement. Chest, 57, 545.

Paton, B. C. (1969). Reoperation for fibrinous stenosis of disc mitral valve prosthesis. J. thorac. cardiovasc. Surg., 57, 726.

Rouleau, C. A., Frye, R. L., and Ellis, F. H. (Jr.) (1969). Hemodynamic state after prosthetic replacement of the mitral valve with a ball or disk valve. In: Prosthetic Heart Valves, edited by L. A. Brewer, p. 444. Thomas, Springfield, Illinois.

Vasko, J. S. (1968). Discussion. Ann. thorac. Surg., 5, 409.

Wright, J. T. M., and Temple, L. J. (1971). An improved method for determining the flow characteristics of prosthetic mitral heart valves. Thorax, 26, 81 .

Yates, A. K. (1969). Artificial heart valves. Brit. J. Hosp. med. Equipment, suppl., p. 4. 